\title{
Synthesis, Characterization and Antidiabetic Activity of Chromium (III) Metformin Complex
}

\author{
Samy M El-Megharbel1,2* \\ ${ }^{1}$ Department of Chemistry, Faculty of Science, Taif University, Al-Haweiah, Taif, Saudi Arabia \\ ${ }^{2}$ Department of Chemistry, Faculty of Science, Zagazig University, Zagazig, Egypt
}

\begin{abstract}
The chromium (III) metformin hydrochloride complex as a diabetic drug model was synthesised by the chemical reaction between chromium (III) chloride hexahydrateand metformin $\mathrm{HCl}(\mathrm{Mfn} . \mathrm{HCl})$ in methanol solvent. The $[\mathrm{Cr}(\mathrm{Mfn}-\mathrm{HCl}) 2(\mathrm{Cl}) 2] . \mathrm{Cl} .6 \mathrm{H} 2 \mathrm{O}$ complex was characterized using microanalytical measurements, molar conductance, spectroscopic (infrared, and UV-vis.), effective magnetic moment, and thermal analyses. The infrared spectroscopic data in the comparison between free $\mathrm{Mfn} . \mathrm{HCl}$ ligand and its chromium (III) complex proved that metformin hydrochloride react with chromium(III) ions as a bidentate ligand through its two imino groups. The anti-diabetic activities of the Mfn. $\mathrm{HCl}$ drug, chromium salt and $\mathrm{Cr}$ (III)-2Mfn. $\mathrm{HCl}$ complex were discussed on the male rats. The chromium (III) metformin $\mathrm{HCl}$ complex was recorded successful efficiency in the decreasing blood glucose level and $\mathrm{HbA} 1 \mathrm{C}$ against diabetic rats. The $\mathrm{Cr}(\mathrm{III})-2 \mathrm{Mfn}$. $\mathrm{HCl}$ complex has succeeded to great extent as antidaibetic drug with enhanced the antioxidant defence system as well as act as pronounced efficient hypoglycaemic agent compared to metformin $\mathrm{HCl}$ free drug.
\end{abstract}

Keywords: Metformin hydrochloride; Chromium(III) complex; Anti-diabetic activity; Spectroscopic; Thermal

\section{Introduction}

Metformin hydrochloride (Mfn.HCl) structure was refered in Figure 1. Diabetes is a metabolic syndrome which was characterized by hyperglycemia and glycosuria resulting from the defect in the secretion or the action of insulin, or both of them [1,2]. Some metal complexes or organo-metallic compounds have been used in medicine for centuries. Supplement contains trivalent chromium was needed for a person with type 2 diabetes mellitus, according to its important role in glucose metabolism [3]. The Cr (III) metal ion interacts with the insulin and its receptors on the first step in the metabolism of glucose entry into the cell, and facilitates the interaction of insulin with its receptor on the cell surface $[4,5]$. Chromium increases insulin binding to cells, insulin receptor number as well as activates insulin receptor kinase leading to increase sensitivity of insulin receptor. Additional studies were urgently needed to elucidate the mechanism of the action of chromium and its role in the prevention and control of diabetes [6]. Metformin, the most common prescribed oral medication in type 2 diabetes, lowers HbAlc around $1.5 \%$, rarely causes hypoglycemia (compared with insulin or sulfonylureas), has relatively few contraindications, its adverse effects are generally tolerable, did not cause weight gain, was cheap, and was highly acceptable among patients [7]. Metformin exerts it was main antihyperglycemic effects through activation of AMP-activated protein kinase, resulting in reduced hepatic gluconeogenesis [8]. In addition, moderate improvements in lipid profile and weight reduction have been reported with metformin use [8]. Herein, this paper reports the synthesis, characterization and chromium (III) metformin complex as a prospective antidiabetic candidate

\section{Experimental}

\section{Materials}

All chemicals, solvents, chromium(III) chloride hexahydrate were commercially available from $\mathrm{BDH}$ and were used without further purification. The pure grade metformin hydrochloride drug was received as a gift sample from Egyptian International Pharmaceutical Industrial Company EIPICo.

\section{Synthesis of Cr(III)-2Mfn.HCl}

The of metformin hydrochloride drug ligand ( $2 \mathrm{mmol}, 0.332 \mathrm{~g}$ ) was dissolved in $25 \mathrm{~mL}$ methanol then mixed with $25 \mathrm{~mL}$ of methanolic solution of $(1 \mathrm{mmol}, 0.267 \mathrm{~g}) \mathrm{CrCl}_{3} \cdot 6 \mathrm{H}_{2} \mathrm{O}$. A mixture of molar ratio of $1: 2$ was heated at $\sim 80^{\circ} \mathrm{C}$ under reflux for about 3 hours. The mixture was left overnight at room temperature until precipitated. The precipitate obtained was filtered off and washed by diethyl ether then left over anhydrous calcium chloride. The yield of the solid leaf green colour powder product was about $\sim 85 \%$. The formula weight of chromium(III) complex is $\mathrm{C}_{8} \mathrm{H}_{36} \mathrm{Cl}_{5} \mathrm{CrN}_{10} \mathrm{O}_{6}$, molecular weight is 597.74 $\mathrm{g} \mathrm{mol}^{-1}$, and the microanalytical data of theoretical and experimental are as follows: theoretical $=\% \mathrm{C}, 16.06 ; \% \mathrm{H}, 6.02 ; \% \mathrm{Cr}, 8.70 ; \% \mathrm{~N}, 23.42$ and experimental=\%C, 15.43; \%H, 5.89; \%Cr, 8.65; \%N, 23.19 .

\section{Instruments}

IR spectra of the Mfn.HCl and its chromium(III) complex were

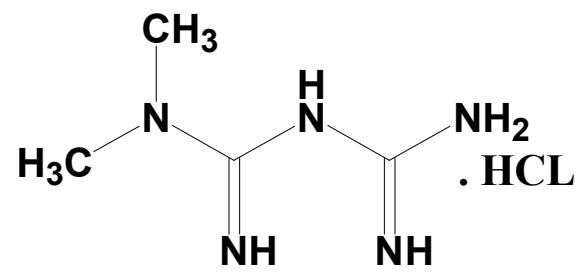

Figure 1: Structure of metformin hydrochloride ligand.

*Corresponding author: Samy M El-Megharbel, Taif University, Taif, Saudi Arabia, Tel:00966554302911; E-mail: samyelmegharbel@yahoo.com

Received February 26, 2015; Accepted March 17, 2015; Published March 24 2015

Citation: El-Megharbel SM (2015) Synthesis, Characterization and Antidiabetic Activity of Chromium (III) Metformin Complex. J Microb Biochem Technol 7: 065075. doi:10.4172/1948-5948.1000184

Copyright: (c) 2015 El-Megharbel SM. This is an open-access article distributed under the terms of the Creative Commons Attribution License, which permits unrestricted use, distribution, and reproduction in any medium, provided the original author and source are credited 
recorded on Bruker infrared spectrophotometer in the range of 400$4000 \mathrm{~cm}^{-1}$, at Taif University. The electronic spectrum of the $\mathrm{Cr}$ (III) complex was measured in DMSO solvent with concentration of $1 \times 10^{-3}$ $\mathrm{M}$, in rang $200-1100 \mathrm{~nm}$ by using Unicam UV/Vis spectrometer. SEM images were obtained using a Jeol Jem-1200 EX II Electron microscope at an acceleration voltage of $25 \mathrm{kV}$. X-ray diffraction (XRD) patterns of the samples were recorded on X Pert Philips X-ray diffractometer. All the diffraction patterns were obtained by using $\mathrm{CuK}_{\mathrm{a} 1}$ radiation, with a graphite monochromator at $0.02 \% \mathrm{~min}$ scanning rate. Carbon, hydrogen and nitrogen analysis have been carried out in Vario EL Fab. CHNS. The amount of water and the metal content percentage were determined by gravimetric analysis method. The molar conductance of $10^{-3} \mathrm{M}$ solutions of the metformin hydrochloride ligand and its chromium(III) complex in DMF solvent were measured on a $\mathrm{HACH}$ conductivity meter model. All the measurements were taken at room temperature for freshly prepared solutions. Differential Thermal Analysis (DTA) and Thermo Gravimetric Analysis (TGA) experiments were conducted using Shimadzu DTA-50 and Shimadzu TGA-50H thermal analyzers, respectively. All experiments were performed using a single loosetop loading platinum sample pan under nitrogen atmosphere at a flow rate of $30 \mathrm{ml} / \mathrm{min}$ and a $10^{\circ} \mathrm{C} / \mathrm{min}$ heating rate for the temperature range $25-800^{\circ} \mathrm{C}$. The mass susceptibility $\left(\mathrm{X}_{\mathrm{g}}\right)$ of the solid chromium (III) complex was measured at room temperature using Gouy's method by a magnetic susceptibility balance from Johnson Metthey and Sherwood model. The effective magnetic moment $\left(\mu_{\mathrm{eff}}\right)$ value was obtained using the following equations (1-3) [9].

$$
\begin{aligned}
& X_{g}=\frac{C_{B a l} L\left(R-R_{0}\right)}{10^{9} M} \\
& \text { Where: } \\
& \mathrm{R}_{\mathrm{o}}=\text { Reading of empty tube } \\
& \mathrm{L}=\text { Sample length }(\mathrm{cm}) \\
& \mathrm{M}=\text { Sample mass }(\mathrm{gm}) \\
& \mathrm{R}=\text { Reading for tube with sample } \\
& \mathrm{C}_{\mathrm{Bal}}=\text { balance calibration constant }=2.086 \\
& X_{M}=X_{g} x M . W t .
\end{aligned}
$$

The values of $X_{M}$ as calculated from equation (2) are corrected for the diamagnetism of the ligand using Pascal's constants, and then applied in Curie's equation (3).

$$
\mu_{e f f}=2.84 \sqrt{X_{M} x \quad T}
$$

Where $\mathrm{T}=\mathrm{t}\left({ }^{\circ} \mathrm{C}\right)+273$

\section{Biological experiments}

Forty male Wistar rats (Weighing 200-250 g), were used in all experiments of this study. They were obtained from the Animal House of the National Research Center (Dokki, Giza, Egypt). The animals were maintained in solid-bottom shoe box type polycarbonate cages with stainless steel wire-bar lids, using a wooden dust free litter as a bedding material. We have followed the European community Directive (86/609/EEC) and national rules on animal care.Hyperglycemic rats were weighed and randomly allocated into 4 groups (10 rats each). One group served as hyperglycemic control. Animals were divided into four groups with 10 animals in each group as following:

\section{Group (1):}

Saline (control) was normal and injected intraperitoneally (I.P) with $0.1 \mathrm{~mL}$ for 30 successive days.

\section{Group (2):}

Control diabetic group was injected (i.P) by a single dose of STZ (50 mg/Kg body weight) [10] for induction of diabetes.

\section{Group (3):}

Diabetic (STZ) + Metformin: diabetic group treated with Metformin (I.P) by a dose (150 mg/kg )[11] for successive 30 days.

Group (4):

Diabetic (STZ) + Metformin $/ \mathrm{Cr}^{+3}$ : diabetic group treated with Metformin $/ \mathrm{Cr}^{+3}$ (I.P) by a dose $(150 \mathrm{mg} / \mathrm{kg}$ ) daily for successive 30 days.

\section{Group (5):}

Diabetic $(\mathrm{STZ})+$ Chromium salt $\left(\mathrm{CrCl}_{3} \cdot 6 \mathrm{H}_{2} \mathrm{O}\right)$ : diabetic rats treated with chromium salt (I.P) by a dose $(150 \mathrm{mg} / \mathrm{Kg})$ daily for successive 30 days.

Induction of hyperglycaemia: Hyperglycemia was induced by a single i.p. injection of STZ $(50 \mathrm{mg} / \mathrm{kg})$ [12]. Briefly, rats were weighed and injected with STZ dissolved in a citrate buffer $(0.1 \mathrm{M}$, $\mathrm{pH}$ 4.5). After $72 \mathrm{~h}$ blood samples were withdrawn from the retroorbital venous plexus under light ether anesthesia and the plasma was separated by centrifugation for the determination of glucose level. The treatment was carried out for 30 days after $72 \mathrm{~h}$ from STZ injection. Only rats with plasma glucose levels more than $230 \mathrm{mg} / \mathrm{dl}$ were selected and considered as hyperglycemic animals that have been subjected to further experimentation. At 7 days post-induction of hyperglycemia, blood glucose was assayed by the glucose oxidase method, using a glucometer. The animals were carefully monitored every day and weighed every week during the experiment.

Collection of blood and organs: Blood samples of the fasted rats were collected from the medial retro-orbital venous plexus immediately with capillary tubes (Micro Haematocrit Capillaries, Mucaps) [13]. About $9 \mathrm{~mL}$ of blood collected in two tubes from each animal, one with EDTA for obtaining plasma, the second was allowed to clot for $30 \mathrm{~min}$. Then, the blood in two tubes was centrifuged at 3,000 rpm for $15 \mathrm{~min}$ to separate serum and plasma for different biochemical analyses.

Lipid profile: Triglycerides, cholesterol and high density lipoprotein-cholesterol (HDL-c) were determined using the commercial kits. Low density lipoprotein-cholesterol (LDL-c) levels were calculated by using the following formula of Muruganandan et al., [14] LDL-c=total cholesterol-(HDL-c + triglycerides $) / 5$. Volatile low density lipoprotein-cholesterol (VLDL-c) levels were calculated by using the following formula of Prakasam et al., [15]: VLDL$\mathrm{c}=$ triglyceride/5. The risk ratio was calculation by dividing the total cholesterol by HDL-c.

\section{Antioxidant abilities}

Assessment of lipid peroxidation as oxidative indicator: Bioindicator in tissues the thiobarbituric acid reactive substances (TBARS) levels as an index of malondialdehyde (MDA) production were measured by the method described by Ohkawa et al., [16]. MDA, an end product of lipid peroxidation reacts with TBA-TCA complex to form a colour complex at high temperature exhibiting an absorption maximum at $535 \mathrm{~nm}$.

Determination of enzymatic and non-enzymatic antioxidants: The principle of SOD activity ability was based on the inhibition of nitro blue tetrazolium (NBT) reduction. Illumination of riboflavin in the presence of $\mathrm{O}_{2}$ and electron donor like methionine generates 
superoxide anions and this has been used as the basis of ability of SOD. The reduction of NBT by superoxide radicals to blue colour formazan was followed at $480 \mathrm{~nm}$ [17]. Reduced glutathione level (GSH) as nonenzymatic antioxidant was estimated based on the method of Beutler et al., [18].

Determination of blood glucose level, $\mathrm{Hb}, \mathrm{HbAlc:} \mathrm{Glucose}$ was estimated by O-toluidine method of Sasaki et al., [19]. Hb was estimated by cyanmethaemoglobin method of Drabkin and Austin [20]. HbAlc was estimated by the method of Sudhakar and Pattabiraman[21] with modification by Bannon [22].

Insulin level and C-peptide: Insulin in pancreatic homogenates was determined by Immulite Insulin (Diagnostic Products Corporation, Los Angeles) which depends on a two-site chemiluminescent enzymelabelled immunometricability [23] Serum C-peptide was measured by radioimmunoassay (Medgenix Diagnostics) as described by Kumar et al., [24]. All chemicals and reagents were of pure analytical grade.

Pancreatic homogenates preparation: At time of death, pancreas tissues were dissected, cleared of lymph nodes and fat, blotted, washed from blood and weighed. The pancreas was immediately homogenized in $5 \mathrm{ml}$ cold $2 \mathrm{M}$ acetic acid for $5 \mathrm{~s}$. The extract was centrifuged at 15 000 r.p.m. for $10 \mathrm{~min}$, and the resulting supernatant was frozen at $-80^{\circ} \mathrm{C}$ until further analysis of insulin.

Electron microscopy: The third portion of the pancreas was immediately cut into small cubes and transferred to ice-cold fixation buffer $(1.25 \% \mathrm{v} / \mathrm{v}$ glutaraldehyde in $0.1 \mathrm{mMcacodylate-HC1}$ buffer, $0.1 \mathrm{M}$ sucrose, and $2 \mathrm{mM}$ calcium chloride $\mathrm{pH}$ 7.2) and prepared for transmission electron microscopy [25].

Statistical analysis: Data were collected, arranged and reported as mean \pm standard error of mean (S.E.M) of four groups (Each group was considered as one experimental unit), summarized and then analyzed using the computer program SPSS/version 15.0) The statistical method was one way analyzes of variance ANOVA test (F-test), and if significant differences between means were found, Duncan's multiple range test (Whose significant level was defined as $(\mathrm{P}<0.05)$ was used according to Snedecor and Cochran, [26] to estimate the effect of different treated groups.

\section{Results and Discussion}

\section{Chemical composition}

The elemental analysis shows that $\mathrm{Cr}$ (III) formed complex with $\mathrm{Mfn} . \mathrm{HCl}$ in 1:2 (Cr(III): $\mathrm{Mfn} . \mathrm{HCl})$ molar ratio. The synthesized $\mathrm{Cr}(\mathrm{III})$ complex is leaf green and soluble in dimethylsulfoxide and dimethylformamide, partially soluble in hot methanol and insoluble in water and some other organic solvents. The conductivity of chromium(III) metformin $\mathrm{HCl}$ complex is measured in DMF solvent at room temperature, that show the molar conductance value of 10 ${ }^{3} \mathrm{~mol} / \mathrm{cm}^{3}$ concentration is $66 \mathrm{ohm}^{-1} \mathrm{~cm}^{2} \mathrm{~mol}^{-1}$. This data reflect that $\mathrm{Cr}(\mathrm{III}) / \mathrm{Mfn}-\mathrm{HCl}$ complex is slightly electrolytic nature [27]. The slightly electrolytic value may be due to the contribution of the one chloride anion in the outer sphere of chelating skeleton of the $\mathrm{Cr}$ (III) metformin complex.

The infrared absorption bands are one of the important tools of analyses used for determining the mode of chelations. The most significant bands of metformin $\mathrm{HCl}$ ligand can be classified into two groups: i) $\mathrm{NH}$ vibrational spectra of primary $\left(-\mathrm{NH}_{2}\right)$, secondary $(-\mathrm{NH})$ and imino $(-\mathrm{C}=\mathrm{NH})$ groups and ii) $\mathrm{C}-\mathrm{N}$ and $\mathrm{C}=\mathrm{N}$ vibration bands of different amino groups $\left(-\mathrm{NH}_{2},-\mathrm{NH}\right.$ and $\left.-\mathrm{C}=\mathrm{NH}\right)$. According to the two fundamental vibrational groups mentioned above, the metformin $\mathrm{HCl}$ free ligand can be interpreted as follows: N-H Vibrations: $\mathrm{i}-\mathrm{N}-\mathrm{H}$ vibrations; the $\mathrm{N}-\mathrm{H}$ stretching of $\mathrm{C}=\mathrm{N}-\mathrm{H}$ group occurs in the region $3400-3100 \mathrm{~cm}^{-1}$. Usually the frequency of this vibration decreases in the presence of the hydrogen bond [28]. The broad bands at 3370 and (3294 and 3174$) \mathrm{cm}^{-1}$ have been assigned to $\mathrm{N}-\mathrm{H}$ asymmetric and symmetric stretching vibrations, respectively [28]. The band at $1570 \mathrm{~cm}^{-1}$ has been assigned for $\mathrm{NH}_{2}$ in the plane deformation vibrations [28]. The bands of the medium-to-weak intensities at 935,798 and $735 \mathrm{~cm}^{-1}$ are due to $\mathrm{N}-\mathrm{H}$ wagging. ii) The strong absorption band at $1627 \mathrm{~cm}^{-1}$ is due to $\mathrm{C}=\mathrm{N}$ stretching vibration [29]. The medium-to-weak intensity bands in the IR spectra at 1271,1168 , and $1061 \mathrm{~cm}^{-1}$ have been assigned to $\mathrm{C}-\mathrm{N}$ stretching vibrations of aliphatic amine compounds. Medium-toweak intensity bands at $639,582,541$, and $419 \mathrm{~cm}^{-1}$ are due to CNC deformation vibrations [29-32].

The presence of the IR spectral bands of the imino group $(-\mathrm{C}=\mathrm{NH})$ in the $\mathrm{Cr}$ (II) complex are shifted in comparison with the metformin $\mathrm{HCl}$ free ligand with significant intensity. This indicates that metformin is coordinated to the metal ions through the nitrogen atom of the imino group. The second evidence which denies the displacement of imino group, is the presence of the stretching vibration band of $v(\mathrm{C}=\mathrm{NH})$ almost shifted and not similar to that of the metformin free ligand. The infrared spectra of distinguish bands of water molecules concerning hydrated $\mathrm{Mfn}-\mathrm{HCl}$ complex exist with overlapping the characteristic bands of the amino group. There is no definite borderline between lattice and coordinated water molecules, especially in the stretching of $\mathrm{OH}$ and bending $\delta\left(\mathrm{H}_{2} \mathrm{O}\right)$ vibration. In addition to these interpretations the new bands at 454 and $421 \mathrm{~cm}^{-1}$ are assigned to the stretching vibration motions of $v(\mathrm{M}-\mathrm{N})$ [33].

Metformin hydrochloride free ligand has absorption in the ultraviolet regions at 228,262, 284 and $375 \mathrm{~nm}$ and in some cases these bands extends over to higher wavelength region due to conjugation. New bands due to charge transfer spectra from metal to ligand (M-L) or ligand to metal (L-M) can be observed and this data can be processed to obtain information regarding the structure and geometry of the complexes [34]. Electronic spectra of $\mathrm{Cr}$ (III) complex was recorded in DMSO with $10^{-3} \mathrm{~mol} / \mathrm{cm}^{3}$. UV-visible peaks corresponding to the $\pi \rightarrow \pi^{*}$ transitions in the Mfn-HClCr(III) complex was observed at 278 and $309 \mathrm{~nm}$. This transitions $\left(\pi \rightarrow \pi^{*}\right)$ could be assigned to the aromaticity of the double bond. The peaks belonging to $n \rightarrow \pi^{*}$ transitions are recorded at wavelengths $432 \mathrm{~nm}$. This is most probably due to the $\mathrm{n} \rightarrow \pi^{*}$ transitions of imine $(=\mathrm{NH})$, primary $\left(-\mathrm{NH}_{2}\right)$, secondary $(-\mathrm{NH})$, and tertiary $\left(-\mathrm{N}\left(\mathrm{CH}_{3}\right)_{2}\right)$ amino groups. The transition in visible region located at $635 \mathrm{~nm}$ for $\mathrm{Cr}$ (III) complex can be attributed to the ligandto-metal charge transfer bands LMCT from the electronic lone pairs of adjacent nitrogen coordinated to the $\mathrm{Cr}$ (III) ions. The electronic spectrum of the Mfn. $\mathrm{HCl}$ ligand exhibited maximum band at $375 \mathrm{~nm}$, which could be assigned to the $n-\pi^{*}$ transition of the imine $(=\mathrm{NH})$, primary $\left(-\mathrm{NH}_{2}\right)$, and secondary $(-\mathrm{NH})$ amino groups. This band show a red shift of the absorbance intensity in $\mathrm{Cr}$ (III) complex. This clearly indicates the coordination of the imine nitrogen atom with the metal atom. The solid reflectance spectrum of $\mathrm{Cr}$ (III) complex display three bands in the range 18,691 $\left(v_{1}\right), 22,472\left(v_{2}\right)$ and $25,126 \mathrm{~cm}^{-1}$, characteristic to an octahedral geometry. These bands may be assigned to the transitions ${ }^{4} \mathrm{~A}_{2 \mathrm{~g}} \rightarrow{ }^{4} \mathrm{~T}_{1 \mathrm{~g}}$ (F) $v_{2}$ and ${ }^{4} \mathrm{~A}_{2 \mathrm{~g}} \rightarrow{ }^{4} \mathrm{~T}_{2 \mathrm{~g}}(\mathrm{~F}) v_{1}$, respectively, and third one is due to the charge transfer. Various ligand field parameters are calculated. The Nephelauxetic parameter $\beta$ is obtained by using the relation: $\beta=B$ (Complex) $/ B$ (Free ion). The $\beta$ values indicate that the complex has appreciable covalent character. Chromium(III) complex shows magnetic moment in the range $3.67 \mathrm{BM}$ recorded at room 
Citation: El-Megharbel SM (2015) Synthesis, Characterization and Antidiabetic Activity of Chromium (III) Metformin Complex. J Microb Biochem Technol 7: 065-075. doi:10.4172/1948-5948.1000184

temperature, corresponding to three unpaired electrons. This value is close to the spin only value [35]. On the basis of the above discussion, the suggested structure of the chromium(III) Mfn- $\mathrm{HCl}$ complex can be represented as in (Figure 2).

The homogeneity, surface morphology and chemical composition of $\mathrm{Mfn}-\mathrm{HCl}$ free ligand and $\mathrm{Cr}^{\mathrm{III}}$ complex were studied using SEM (Figure 3). The surface morphology of SEM micrograph reveals the well uniform nature of the $\left[\mathrm{Cr}(\mathrm{Mfn}-\mathrm{HCl})_{2}(\mathrm{Cl})_{2}\right] \cdot \mathrm{Cl} \cdot 6 \mathrm{H}_{2} \mathrm{O}$ complex with variant grain sizes and shapes. Clear large grains are obtained with agglomerates. The distribution of the grain size is homogeneous. X-ray

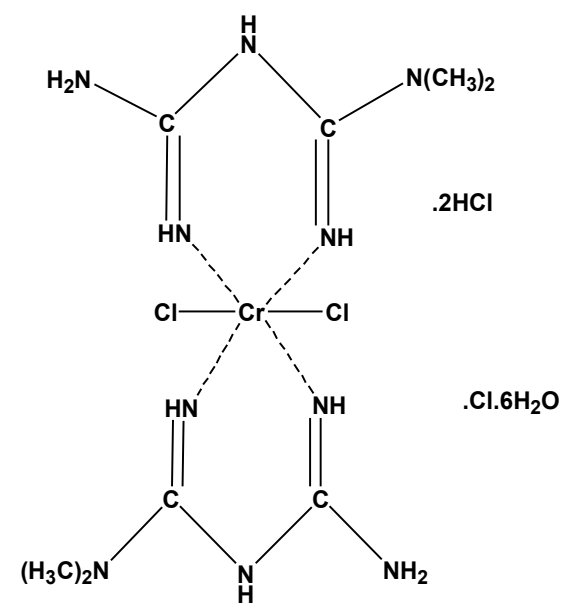

Figure 2: Suggested chelating of $\left[\mathrm{Cr}(\mathrm{Mfn}-\mathrm{HCl})_{2}(\mathrm{Cl})_{2}\right] \cdot \mathrm{Cl} \cdot 6 \mathrm{H}_{2} \mathrm{O}$ complex.

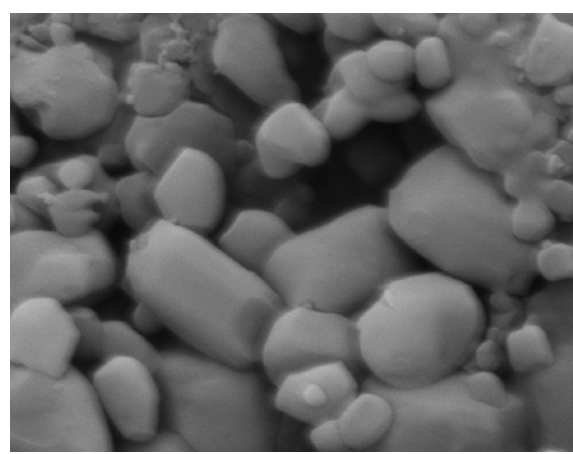

Figure 3a: SEM photos of Mfn-HCl free drug

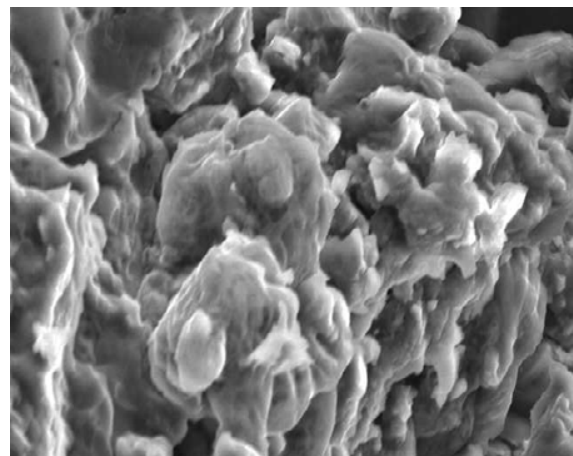

Figure 3b: SEM photos of $\left[\mathrm{Cr}(\mathrm{Mfn}-\mathrm{HCl})_{2}(\mathrm{Cl})_{2}\right] \cdot \mathrm{Cl} 6 \mathrm{H}_{2} \mathrm{O}$ complex.
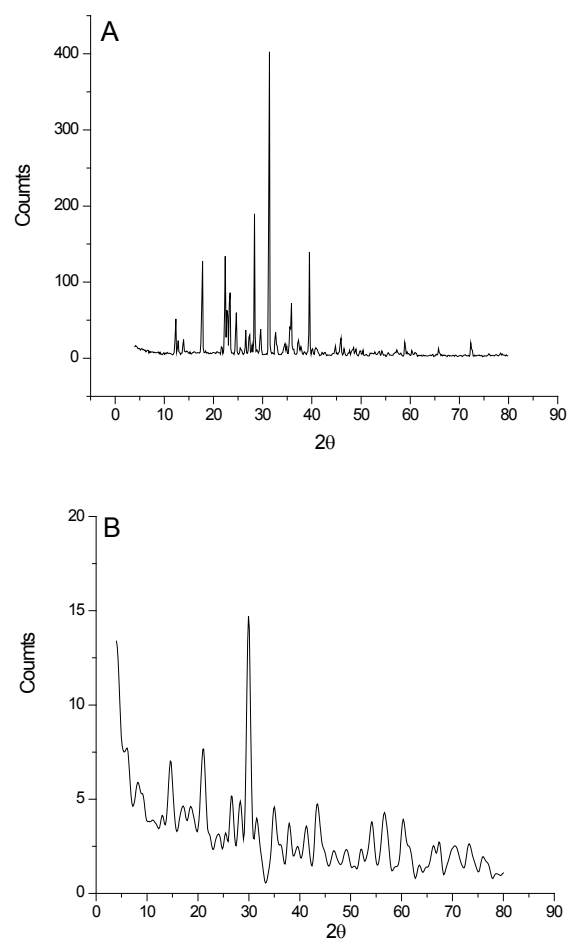

Figure 4: $\mathrm{XRD}$ patterns of $\mathrm{A}-\mathrm{Mfn}-\mathrm{HCl}$ free drug and $\mathrm{B}-\mathrm{C}$ [ $(\mathrm{Mfn}-$ $\left.\mathrm{HCl})_{2}(\mathrm{Cl})_{2}\right] \cdot \mathrm{Cl} \cdot 6 \mathrm{H}_{2} \mathrm{O}$ complex.

powder diffraction patterns in the range of $5^{\circ}<2 \theta<80^{\circ}$ of the Mfn-HCl free ligand and $\mathrm{Cr}^{\mathrm{III}}$ complex were done. The diffractograms collected for these compounds are given in (Figure 4). The definite diffraction data like angle $\left(2 \theta^{\circ}\right)$, interplanar spacing ( $\mathrm{d}$ value, Angstrom), and relative intensity (\%) have been discussed. The X-ray patterns refer to the amorphous nature for $\mathrm{Cr}(\mathrm{III}) / \mathrm{Mfn}-\mathrm{HCl}$ complex. The variable diffractograms of $\mathrm{Cr}^{\mathrm{III}}$ complex can be attributed to the formation of new structure. The maximum diffraction patterns of $\mathrm{Mfn}-\mathrm{HCl}$ and $\mathrm{Cr}^{\mathrm{III}}$ complex exhibited at $2 \theta$ [36] (relative intenisty) $=31(100 \%)$ and 29 (100\%), respectively. The crystallite size could be estimated from XRD patterns by applying FWHM of the characteristic peaks using De byScherrer equation 4 [37].

\section{$\mathrm{D}=\mathrm{K} \lambda / \beta \operatorname{Cos} \theta$}

Where $\mathrm{D}$ is the particle size of the crystal gain, $\mathrm{K}$ is a constant (0.94 for Cu grid), $\lambda$ is the X-ray wavelength (1.5406 $\AA$ ), $\theta$ is the Bragg diffraction angle and $\beta$ is the integral peak width. The particle size was estimated according to the highest value of intensity compared with the other peaks.

The thermal degradation behaviour of $\mathrm{Cr}(\mathrm{III}) / \mathrm{Mfn}-\mathrm{HCl}$ drug complex is one of the interesting tools to confirm the composition and assessment of the role of metal ions. The thermal analysis of metformin hydrochloride free ligand shows two main consecutive steps of mass loss at the temperature ranges $\left(181-410^{\circ} \mathrm{C}\right)$ and $\left(410-600^{\circ} \mathrm{C}\right)$. At the first step $\left(181-410^{\circ} \mathrm{C}\right)$, the mass loss of $80.70 \%$ with maximum rate $\left(\mathrm{T}_{D T G}\right)$ at $271^{\circ} \mathrm{C}$, corresponds to an endothermic volatilization of hydrogen chloride molecule together with $\mathrm{C}_{4} \mathrm{~N}_{3} \mathrm{H}_{7}$ fragment (calcd.=80.67\%) at $\mathrm{T}_{d t a}$ of $234^{\circ} \mathrm{C}$. The mass loss $(19.30 \%)$ at the second step $\left(410-600^{\circ} \mathrm{C}\right)$ of DTG at $504{ }^{\circ} \mathrm{C}$ as assigned to the exothermic release of $\mathrm{H}_{4} \mathrm{~N}_{2}$ fragment (calcd. $=19.33 \%$ ) at $\mathrm{T}_{d t a}$ of $516^{\circ} \mathrm{C}$. 
The TG/DTG curves recorded for the $\left[\mathrm{Co}(\mathrm{Mfn}-\mathrm{HCl})_{2}(\mathrm{Cl})_{2}\right]$. $\mathrm{Cl} .6 \mathrm{H}_{2} \mathrm{O}$ complex are given in Figure 5. This curve, which characterize and compare the thermal decomposition behaviour of the $\mathrm{Mfn}-\mathrm{HCl}$ ligand show seven (weak-to-very strong intensities) continuities successive degradation steps at 30-97, 97-168, 168-315, 315- 47, 447$490,490-546$ and $666-740^{\circ} \mathrm{C}$. The first-to-third step at $T_{D T G}$ of 60,131 and $2272^{\circ} \mathrm{C}$, the mass loss of $17.00 \%$ is consistent with the evolution of six uncoordinated water molecules (Cal. 18.07\%). Consequently, the fourth-to-seventh steps existed at 315-447, 447-490, 490-546 and $666-740^{\circ} \mathrm{C}$ with endothermally $\left(T_{d t g}\right)$ at $360,465,514$ and $700^{\circ} \mathrm{C}$, respectively, are assigned to the decomposition of two $\mathrm{Mfn}-\mathrm{HCl}$ and three chlorine atoms. The finalresidual is chromium oxide $\left(\mathrm{CrO}_{1.5}\right)$ (Cal. $12.71 \%$, found $12.00 \%$ ).

The kinetic and thermodynamic parameters were determined using non-isothermal methods. The non-isothermal kinetic analysis for the thermal decomposition of $\mathrm{Mfn}-\mathrm{HCl}$ ligand and $\mathrm{Cr}(\mathrm{III})$ complex in this work was carried out by the application of the Coats-Redfern[38] and Horowitz-Metzger method [39] methods. From the TGA curves (TG/ DTG) recorded for the successive steps in the decomposition process of $\mathrm{Mfn}-\mathrm{HCl}$ ligand and its $\mathrm{Cr}$ (III) complex, it was possible to determine the following characteristic thermal parameters for each reaction step as follows: Initial point temperature of decomposition $\left(\mathrm{T}_{i}\right)$ : the point at which DTG curve starts deviating from its base line. Final point temperature of decomposition $\left(\mathrm{T}_{f}\right)$ : the point at which DTG curve returns to its base line. Peak temperature, i.e. temperature of maximum rate of mass loss $\left(\mathrm{T}_{\text {DтG }}\right)$ : the point obtained from the intersection of tangents to the peak of DTG curve. Mass loss at the decomposition step $(\Delta \mathrm{m})$ : it is the amount of mass that extends from the point $\mathrm{T}_{i}$ up to the point $\mathrm{T}$ on the TG curve. The material released at each step of the decomposition is identified by attributing the mass loss $(\Delta \mathrm{m})$ at a given step to the component of similar weight calculated from the molecular formula of the investigated compounds, comparing that with literatures of relevant compounds considering their temperature. This may assist identifying the mechanism of reaction in the decomposition steps taking place in the complex under study. Activation energy $\left(\mathrm{E}^{*}\right)$ of the decomposition step: the integral method used is the CoatsRedfern equation [38] for reaction order $n \neq 1$, which when linearized for a correctly chosen $n$ yields the activation energy from the slope;

$$
\log \left[\frac{1-(1-\alpha)^{1-n}}{T^{2}(1-n)}\right]=\log \frac{Z R}{q E_{a}}\left[1-\frac{2 R T}{E_{a}}\right]-\frac{E_{a}}{2.303 R T} \quad \text { for } n \neq 1
$$

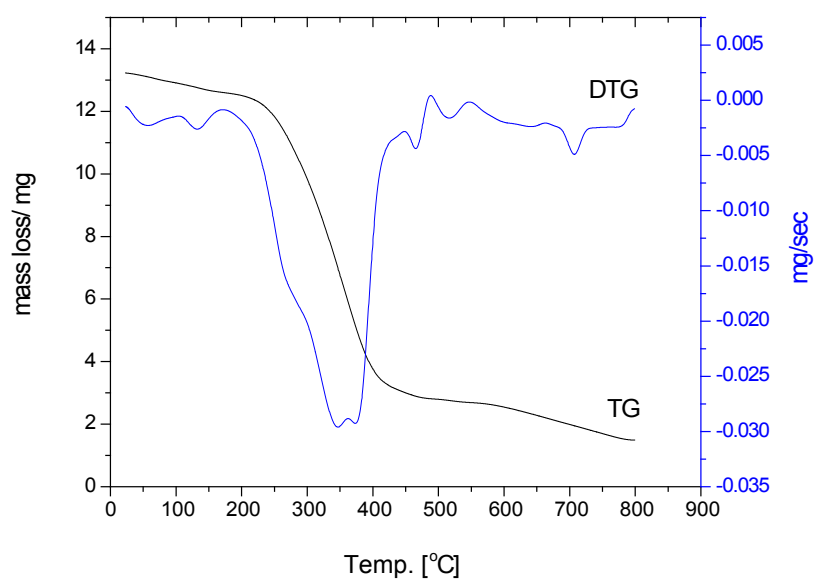

Figure 5: TG and DTG curves of $\left[\mathrm{Cr}(\mathrm{Mfn}-\mathrm{HCl})_{2}(\mathrm{Cl})_{2}\right] \cdot \mathrm{Cl} 6 \mathrm{H}_{2} \mathrm{O}$ complex.

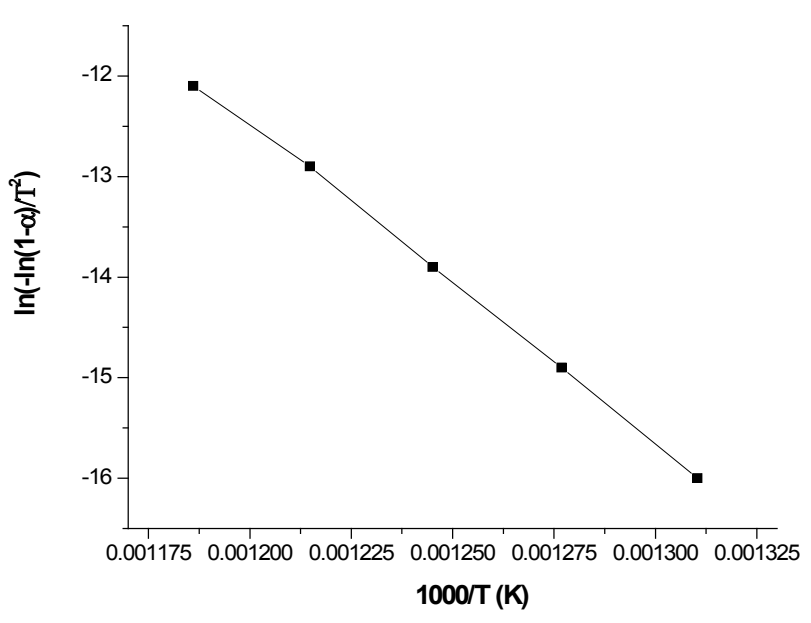

Figure 6: Coats-Redfern (CR) plot of $\left[\mathrm{Cr}(\mathrm{Mfn}-\mathrm{HCl})_{2}(\mathrm{Cl})_{2}\right] \cdot \mathrm{Cl} 6 \mathrm{H}_{2} \mathrm{O}$ complex.

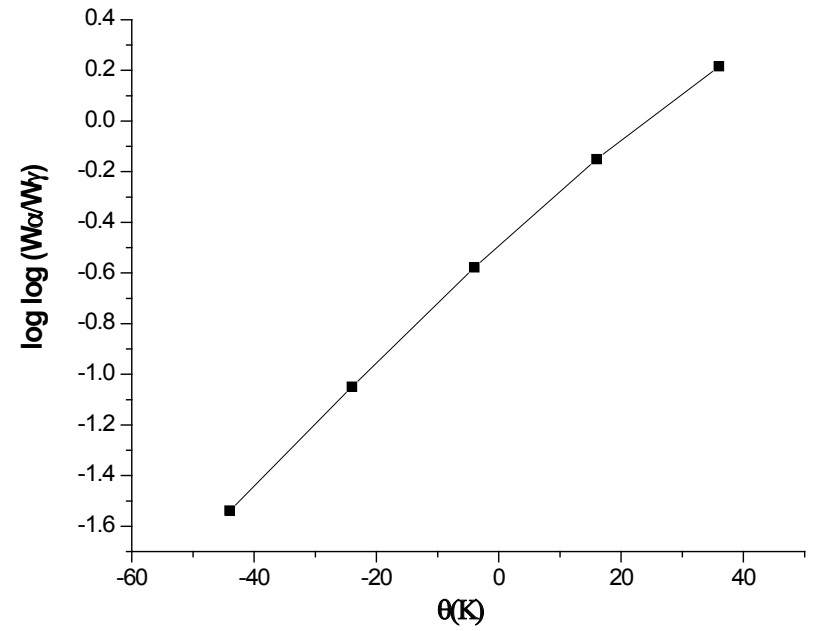

Figure 7: Horowitz-Metzger ( $\mathrm{HM})$ plot of $\left[\mathrm{Cr}(\mathrm{Mfn}-\mathrm{HCl})_{2}(\mathrm{Cl})_{2}\right] \cdot \mathrm{Cl}_{2} 6 \mathrm{H}_{2} \mathrm{O}$ complex.

$$
\log \left[\frac{-\log (1-\alpha)}{T^{2}}\right]=\log \frac{Z R}{q E_{a}}\left[1-\frac{2 R T}{E_{a}}\right]-\frac{E_{a}}{2.303 R T} \quad \text { for } \quad n=1
$$

Where: $\alpha=$ fraction of weight loss, $\mathrm{T}=$ temperature $(\mathrm{K}), n=$ order of reaction, $\mathrm{Z}=$ pre-exponential factor, $\mathrm{R}=$ molar gas constant, $E$ =activation energy and $\mathrm{q}=$ heating rate. The activation energies $\left(E_{a}\right)$ are calculated from the slopes of the best fit straight lines $(\mathrm{r} \approx 1)$ obtained when the plots of the Coats-Redfern equation [38] are used for the best values of reaction order $(n)$. Order of reaction $(n)$ : it is the one for which a plot of the Coats-Redfern expression gives the best straight line (Figure 6) among various trial values of $n$ that are examined, i.e., by trial and error for various trial values of $n$, estimated by the Horowitz-Metzger method [39] (Figure7). The thermodynamic parameters: entropy change $\left(\Delta S^{*}\right)$, enthalpy change $\left(\Delta H^{*}\right)$ and free energy of activation change $\left(\Delta G^{\star}\right)$ were calculated using the following equations:

$$
\begin{aligned}
& \Delta S^{*}=R[\ln (Z h / K T)] \\
& \Delta H^{*}=E_{a}-R T_{s} \\
& \Delta G^{*}=\Delta H^{*}-T_{s} \Delta S^{*}
\end{aligned}
$$


Where, $\mathrm{Z}, \mathrm{K}$ and $h$ are the pre-exponential factor, Boltzman and Plank constants, respectively [40].

The negative $\Delta S^{*}$ values indicate that the activated complex has more ordered structure than the reactants and the reactions are slower than normal [41]. The positive values of $\Delta G^{*}$ indicate the nonspontaneous character for the reactions at the transition-state. The positive $\Delta H^{\star}$ values show endothermic transition-state reactions [42]. From the abnormal values of $Z$,the reactions of the complexes at the transition-state can be classified as a slow reaction [43]. The higher stability of the $\mathrm{Cr}$ (III) complex than that of the $\mathrm{Mfn}-\mathrm{HCl}$ ligand may be due to the formation of two stable 6-membered rings structures in the metal complexes [44] and the higher is the molecular symmetry the more stable is the molecule [45].

\section{Biological evaluation}

Effect on Superoxide Dismutase (SOD), Total Antioxidant Capacity (TAC), Malondialdhyde (MDA) and Glutathione Reduced (GSH):

Effect on SOD: The results revealed that the administration of Metformin $/ \mathrm{Cr}^{+3}$ to diabetic rats afforded slight significant decrease when compared to control group while afforded highly significant increase in SOD activity as compared to diabetic control group (STZ). It was recorded from table 1 that diabetic untreated group elicited highly significant decrease in SOD when compared to normal control group. However, diabetic group treated with Metformin elicited significant decrease in SOD activity when compared with normal control group by $31.65 \%$. However, Chromium salt treated group elicited non-significant decrease in SOD activity when compared with normal control group.

Effect on GSH\%: Regarding the effect of Metformin and Metformin $/ \mathrm{Cr}^{+3}$ complex on GSH content, It was shown that diabetic untreated group elicited highly significant decrease in GSH content as compared to normal control group while combination of Metformin/ $\mathrm{Cr}^{+3}$ induced slight significant decrease in GSH content when compared to normal control group by $5.21 \%$ followed by diabetic group treated with Metformin as compared to normal control group. The chromium salt treated group elicited slight decrease in GSH level as shown in table 1.

Effect on MDA\%: Table 1 illustrates that administration of STZ only to rats afforded highly significant increase in MDA content by $71.73 \%$ as compared to normal control group while diabetic group treated with Metformin $/ \mathrm{Cr}^{+3}$ afforded non-significant increase in MDA content as compared to normal control group. While other diabetic group treated with Metformin showed significant increase in MDA

\begin{tabular}{|c|c|c|c|c|}
\hline Groups & SOD (U/mg) & TAC $\%$ & MDA(U/mg) & GSH (U/mg) \\
\hline $1^{\text {st }}$ & $2.78 \pm 0.36^{\text {ab }}$ & $100.00 \pm 1.01^{\mathrm{a}}$ & $104.52 \pm 4.63^{\mathrm{d}}$ & $95.25 \pm 4.15^{\mathrm{a}}$ \\
\hline $2^{\text {nd }}$ & $0.81 \pm 0.17^{\mathrm{d}}$ & $34.78 \pm 5.96^{\mathrm{d}}$ & $368.36 \pm 6.57^{\mathrm{a}}$ & $22.35 \pm 1.95^{\mathrm{d}}$ \\
\hline $3^{\text {rd }}$ & $1.90 \pm 0.15^{\mathrm{c}}$ & $68.25 \pm 5.24^{\mathrm{c}}$ & $156.53 \pm 3.85^{\mathrm{b}}$ & $62.96 \pm 8.52^{\mathrm{c}}$ \\
\hline $4^{\text {th }}$ & $2.25 \pm 0.14^{\mathrm{b}}$ & $80.69 \pm 7.95^{\mathrm{b}}$ & $106.38 \pm 4.10^{\text {cd }}$ & $90.25 \pm 6.45^{\mathrm{b}}$ \\
\hline $5^{\text {th }}$ & $2.20 \pm 0.11^{\mathrm{b}}$ & $79.25 \pm 3.25^{\text {bc }}$ & $110.41 \pm 3.24^{\mathrm{c}}$ & $90.58 \pm 4.07^{\mathrm{b}}$ \\
\hline
\end{tabular}

Data presented as mean \pm S.E. $(n=10)$.

Low density lipoprotein cholesterol (LDL-c)=Total cholesterol- $(\mathrm{HDL}-\mathrm{C}+$ triglyceride) $/ 5$, volatile low density lipoprotein cholesterol $(\mathrm{VLDL}-\mathrm{c})=$ Triglycerides $/ 5$, Risk ratio=Total cholesterol/high density lipoprotein cholesterol (HDL-c)

Means within the same column in each category carrying different litters are significant at $(P \leq 0.05)$ using Duncan's multiple range tests, where the highest mean value has symbol (a) and decreasing in value were assigned alphabetically.

Table 1: Effect of Metformin and Metformin $/ \mathrm{Cr}^{+3}$ complex on Superoxide dismutase (SOD), Total antioxidant capacity (TAC), Malondialdhyde (MDA) and Glutathione reduced $(\mathrm{GSH})$ in normal and diabetic rats. content but the effect was much less intense in diabetic group treated with Metformin as compared to diabetic untreated group, a slight decrease was recorded in chromium salt treated group as compared to normal control group.

Effect on TAC\%: It was apparent from table 1 that administration of STZ only to rats afforded highly significant decrease in TAC activities as compared to normal control group by $65.22 \%$. Meanwhile, administration of Metformin $/ \mathrm{Cr}^{+3}$ afforded significant increase in TAC activities when compared to diabetic untreated group while elicited slight decrease when compared to normal control group. While another diabetic treated group with Metformin exhibited significant decrease in TAC \% activity as compared to normal control group. The chromium salts treated group afforded slight decrease in TAC activity as compared to normal control group and showed non-significant changes as compared to Metformin $/ \mathrm{Cr}^{+3}$ complex treated group. But the diabetic group that recorded the highly TAC\% value is the diabetic group treated with Metformin $/ \mathrm{Cr}^{+3}$ as compared to normal control group and other diabetic groups .

ROS include superoxide free radicals, hydrogen peroxide, singlet oxygen, nitric oxide (NO), and peroxynitrite [52] that if expressed at increased concentrations can lead to cellular injury and demise through oxidative stress [53]. Most ROS occur at low levels and are scavenged by endogenous antioxidant systems that include superoxide dismutase (SOD), glutathione peroxidase, catalase, and small molecule substances such as vitamins $\mathrm{C}, \mathrm{D}, \mathrm{E}$, and $\mathrm{K}[54,55]$. Yet, one vitamin in particular, namely nicotinamide may be considered to stand-alone among antioxidants since nicotinamide influences multiple pathways tied to both cellular survival and cellular death. In several scenarios, nicotinamide is a robust cytoprotectant that addresses both early membrane PS externalization and later genomic DNA degradation $[56,57]$ during oxidative stress in a way that is different from other vitamin entities and these findings go hand in hand with our results. In addition, nicotinamide prevents membrane PS exposure in vascular cells [58] that can reduce risk for cardiovascular disorders.

Oxidative stress is one of the most dangerous effects on the cellular activities and thus according to our results complexation between $\mathrm{Cr}^{+3}$ and Metformin greatly scavenged free radical molecules and thus decreased MDA level as it is the final end product of lipid peroxidation and also increased the enzymatic capacities of SOD and GSH and thus improving liver function activities and thus enhancing the conversion of blood glucose into glycogen and thus decreasing blood glucose level which reflect the solution for diabetes mellitus complications.

\section{Effect on blood glucose level, $\mathrm{Hb}, \mathrm{HbA1C}$}

Effect on blood glucose level: It was clear from Table 2 that the administration of STZ in its recommended dose afforded highly significant increase in blood glucose level when compared with normal control group. While administration of Metformin to diabetic rats afforded significant increase in blood glucose level when compared with normal control group but still showed significant decrease in blood glucose level as compared to diabetic untreated group, Meanwhile administration of Metformin $/ \mathrm{Cr}^{+3}$ complex to diabetic rats afforded non-significant increase in blood glucose level when compared with normal control group but showed more better results than other diabetic treated and untreated groups. The chromium salts treated group elicited slight significant increase in blood glucose level as compared to normal control group.

DM affects both young and older individuals [59] and complexation of $\mathrm{Cr}^{+3}$ with Metformin succeed to great extent in reducing blood 
glucose level and this explain the important role of $\mathrm{Cr}^{+3}$ in decreasing blood glucose level after complexation with Metformin. Supplement contains trivalent Chromium is needed for a person with type 2 diabetes mellitus, according to its important role in glucose metabolism [61] and this is greatly confirmed and reinforced our findings as the combination of Metformin with $\mathrm{Cr}(\mathrm{III})$ afforded a significant reduction in blood glucose level as compared to diabetic untreated group.

It was well known that hyperglycemia is the hallmark of diabetes. Our findings are greatly supported by Hai-yan et al. [46] as they showed that an increase in blood glucose was observed after treating with alloxanintraperitoneally and after 15 day's administration of Chromium methionine (CrMet), the blood glucose levels significantly decreased in comparison with the diabetic control group. These findings indicated that CrMet had hypoglycemic effect on AID mice.

Our results are in accordance with Sahin et al. [62] as they indicated that the anti-hyperglycemic activity of CrMet was superior to that of $\mathrm{CrCl}_{3} \cdot 6 \mathrm{H}_{2} \mathrm{O}$ and equivalent to that of CrNic. Ghiasi et al. [63] found out that supplemental CrMet in the diet for 6 weeks could significantly decrease the blood glucose levels of fructose-fed diabetic rat.

Effect on $\mathrm{Hb} \%$ : The results revealed that diabetic untreated group (STZ) elicited highly significant decrease in $\mathrm{Hb}$ content when compared to normal control group as shown in table 2. While treatment of diabetic rats with Metformin $/ \mathrm{Cr}^{+3}$ elicited non-significant decrease in $\mathrm{Hb}$ content as compared to normal control group, while, other diabetic group treated with Metformin showed significant decrease in $\mathrm{Hb}$ content when compared to normal control group. While, chromium salts treated group elicited slight decrease in $\mathrm{Hb}$ level as compared to normal control group.

Effect on HbA1C: After 4 weeks post administration of STZ and other treatments, the diabetic untreated group afforded significant increase in HbAlc compared to normal control group followed by diabetic group treated with Metformin by $23.69 \%$ as compared to normal control group. Whereas treatment of diabetic rats with Metformin $/ \mathrm{Cr}^{+3}$ afforded non-significant increase in $\mathrm{HbAlc}$ as compared to normal control group and thus showing the best results in treating diabetes mellitus table 2 , meanwhile, chromium salt treated

\begin{tabular}{|c|c|c|c|}
\hline Groups & Blood glucose level (mg/dl) & $\mathbf{H b}(\mathbf{g} / \mathbf{d l})$ & HbA1C $(\mathbf{g} / \mathbf{d l})$ \\
\hline $1^{\text {st }}$ & $74.92 \pm 7.50^{\mathrm{e}}$ & $12.43 \pm 2.95^{\mathrm{ab}}$ & $7.30 \pm 1.20^{\mathrm{d}}$ \\
\hline $2^{\text {nd }}$ & $348.19 \pm 30.52^{\mathrm{a}}$ & $8.04 \pm 1.54^{\mathrm{e}}$ & $9.58 \pm 1.03^{\mathrm{a}}$ \\
\hline $3^{\text {rd }}$ & $140.80 \pm 9.82^{\mathrm{b}}$ & $10.20 \pm 1.99^{\mathrm{d}}$ & $9 . .40 \pm 1.01^{\mathrm{b}}$ \\
\hline $4^{\text {th }}$ & $82.40 \pm 8.76^{\text {de }}$ & $12.30 \pm 1.92^{\mathrm{b}}$ & $7.31 \pm 1.24^{\mathrm{d}}$ \\
\hline $5^{\text {th }}$ & $86.24 \pm 5.20^{\mathrm{c}}$ & $11.20 \pm 1.42^{\mathrm{c}}$ & $7.53 \pm 1.04^{\text {cd }}$ \\
\hline
\end{tabular}

Data presented as mean \pm S.E. $(n=10)$.

Means within the same column in each category carrying different litters are significant at $(P \leq 0.05)$ using Duncan's multiple range tests, where the highest mean value has symbol (a) and decreasing in value were assigned alphabetically.

Table 2: Effect of Metformin and Metformin $/ \mathrm{Cr}^{+3}$ complex on blood glucose level, $\mathrm{Hb}, \mathrm{HbA} 1 \mathrm{C}$ in normal and diabetic rats. group afforded non-significant increase in glycated haemoglobin as compared to normal control group.

In uncontrolled or poorly controlled diabetes, there is an increased glycosylation of a number of protein including haemoglobin [60]. Glycosylated hemoglobin (HbA1C) was significantly increased in diabetic animals and this increase was found to be directly proportional to the fasting blood glucose level. During diabetes, the excess glucose present in blood reacts with hemoglobin. Therefore, the total hemoglobin level is decreased in diabetic rats [64]. In this study a decrease in total hemoglobin during diabetes has been observed in diabetic untreated group and this may be due to the formation of glycosylation hemoglobin. Administration of Metformin/ $/ \mathrm{Cr}^{+3}$ to diabetic rats prevent a significant elevation in glycosylated hemoglobin. Thereby increasing the level of total hemoglobin in diabetic rats. This could be due to the improved glycaemic control produced by this new complex.

\section{Effect on lipid profile}

Effect on cholesterol: Table 3 and Figure 8 demonstrates that diabetic untreated rats (STZ) afforded a significant increase in cholesterol level as compared to normal control group while treatment of diabetic rats with Metformin $/ \mathrm{Cr}^{+3}$ elicited non-significant changes in cholesterol level when compared with normal control group while other diabetic group treated with Metformin afforded significant elevation in cholesterol when compared with normal control group while both groups treated with either Metformin or Metformin $/ \mathrm{Cr}^{+3}$ showed significant decrease in cholesterol level when compared with diabetic untreated group but the effect was more intense in diabetic group treated with Metformin $/ \mathrm{Cr}^{+3}$. The non-significant increase in cholesterol level was reported in group treated with $\mathrm{CrCl}_{3} \cdot \mathrm{H}_{2} \mathrm{O}$ treated group as compared to normal control group.

Our obtained results are greatly in accordance with Hai-yan et al. [46] as they tested the anti-diabetic activity of Chromium methionine (CrMet) in detail. Their obtained results showed that CrMet had beneficial effects on glucose and lipid metabolism, and might possess hepatoprotective efficacy for diabetes.

Effect on triglycerides: It was clear from table 3 and Figure 8 that diabetic untreated group showed significant elevation in TG levels as compared to normal control group by $59.12 \%$. However, diabetic group treated with Metformin $/ \mathrm{Cr}^{+3}$ afforded non-significant increase in TG levels as compared to normal control group while showed significant decrease in TG levels as compared to diabetic untreated group. On the other hand, other diabetic group treated with Metformin elicited significant increase in TG levels when compared to normal control group but the best results and the less TG increment was noticed in group treated with Metformin $/ \mathrm{Cr}^{+3}$. Meanwhile, chromium treated group elicited non-significant increase in Triglycerides level as compared to normal control group.

\begin{tabular}{|c|c|c|c|c|c|c|}
\hline Groups & Cholesterol (mg/dl) & Triglycerides $(\mathbf{m g} / \mathbf{d l})$ & HDL-c (g/dl) & LDLc (g/dl) & VLDLc (g/dl) & Risk ratio \\
\hline $1^{\text {st }}$ & $73.22 \pm 5.78^{\mathrm{d}}$ & $90.23 \pm 4.23^{\mathrm{d}}$ & $38.52 \pm 2.88^{\mathrm{a}}$ & $28.63 \pm 9.95^{\mathrm{d}}$ & $18.04 \pm 2.96^{\mathrm{c}}$ & $1.90 \pm 0.45^{\mathrm{d}}$ \\
\hline $2^{\text {nd }}$ & $269.32 \pm 11.03^{\mathrm{a}}$ & $220.75 \pm 10.66^{\mathrm{a}}$ & $5.45 \pm 2.45^{\mathrm{e}}$ & $58.63 \pm 7.09^{\mathrm{a}}$ & $44.15 \pm 3.41^{\mathrm{a}}$ & $49.41 \pm 0.55^{\mathrm{a}}$ \\
\hline $3^{\text {rd }}$ & $97.36 \pm 6.54^{\mathrm{b}}$ & $119.48 \pm 4.23^{\mathrm{b}}$ & $24.44 \pm 1.32^{\mathrm{d}}$ & $39.52 \pm 2.49^{\mathrm{b}}$ & $23.89 \pm 2.85^{\mathrm{b}}$ & $3.98 \pm 0.32^{\mathrm{b}}$ \\
\hline $4^{\text {th }}$ & $74.25 \pm 1.72^{\mathrm{d}}$ & $94.15 \pm 5.44^{\text {cd }}$ & $32.36 \pm 3.98^{\mathrm{b}}$ & $29.75 \pm 4.60^{\text {cd }}$ & $18.83 \pm 1.95^{\mathrm{c}}$ & $2.29 \pm 0.57^{\mathrm{c}}$ \\
\hline $5^{\text {th }}$ & $76.25 \pm 3.20^{\text {cd }}$ & $93.20 \pm 2.10^{\text {cd }}$ & $31.25 \pm 1.20^{\mathrm{c}}$ & $28.50 \pm 3.54^{\mathrm{d}}$ & $18.64 \pm 1.20^{\mathrm{c}}$ & $2.10 \pm 0.24^{\mathrm{c}}$ \\
\hline
\end{tabular}

Data presented as mean \pm S.E. $(n=10)$.

Means within the same column in each category carrying different litters are significant at $(P \leq 0.05)$ using Duncan's multiple range tests, where the highest mean value has the symbol (a) and decreasing in value were assigned alphabetically.

Table 3: Effect of Metformin and Metformin $/ \mathrm{Cr}^{+3}$ complex on the lipid profile in normal and diabetic rat. 


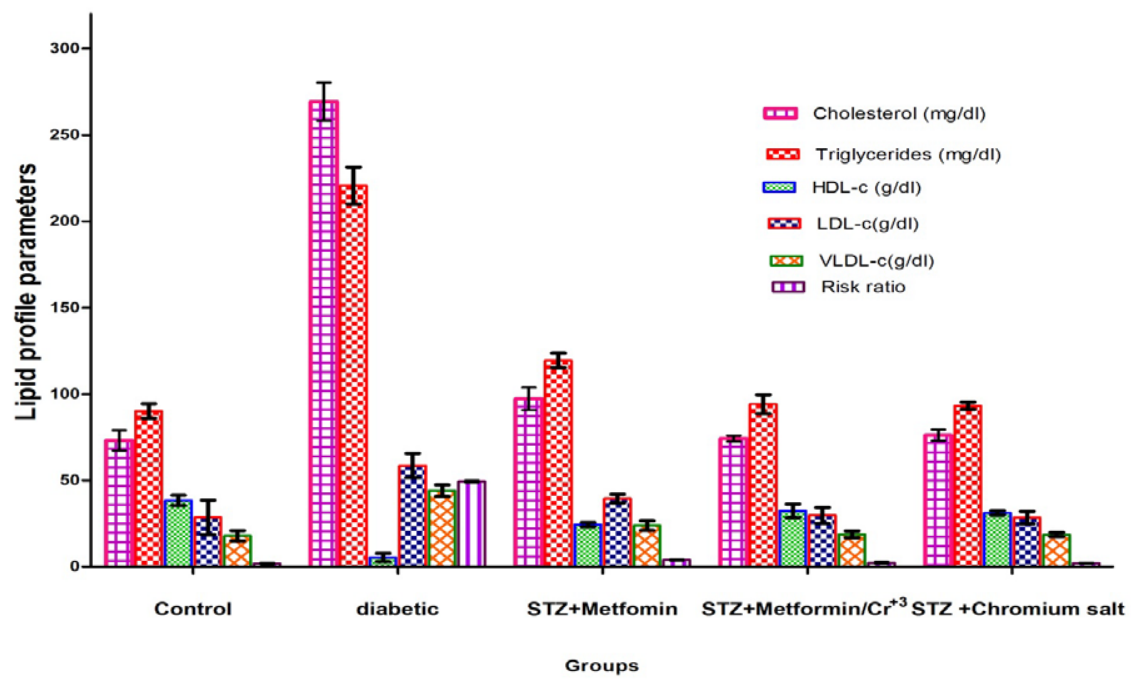

Figure 8: Effect of $\mathrm{CrCl}_{3} \cdot 6 \mathrm{H}_{2} \mathrm{O}$ (Chromium salt), $\mathrm{Mfn}-\mathrm{HCl}$ and $\mathrm{Mfn}-\mathrm{HCl} / \mathrm{Cr}^{+3}$ complex on the lipid profile in normal and diabetic rat.

Effect on HDL-c: The administration of diabetic rats with Metformin $/ \mathrm{Cr}^{+3}$ afforded slight decrease in HDL-c levels when compared to normal control group while diabetic untreated group elicited highly significant decrease in HDL-c levels as compared to normal control group, At the mean time the diabetic group treated with Metformin elicited significant decrease in HDL-c level with respect to normal control group Figure 8. Chromium treated group afforded slight significant decrease in HDL-c level as compared to normal control group.

Effect on LDL-c: At the same time, Table 3 and Figure 8 demonstrates that administration of Metformin $/ \mathrm{Cr}^{+3}$ to diabetic rats exhibited non-significant changes in LDL-c levels as compared to a normal control group. Meanwhile diabetic untreated group induced significant increase in LDL-c levels as compared to a normal control group and also as compared to diabetic group treated with Metformin. Regarding the chromium treated group, it is afforded non-significant decrease in LDL-c level in comparison with normal control group.

Effect on vLDL-c: Table 3 and Figure 8 illustrates the effect of Metformin and Metformin/ $\mathrm{Cr}^{+3}$ complex on vLDL-c, there was significant increase in diabetic untreated group in response to administration of STZ only to rats. At the same time, the treatment of diabetic rats with Metformin $/ \mathrm{Cr}^{+3}$ afforded significant decrease in vLDl-c as compared to diabetic rats by $57.34 \%$. While showed nonsignificant increase when compared to normal control group. At the meantime, diabetic group treated with Metformin showed significant decrease in vLDL-c when compared to diabetic untreated group and showed significant increase when compared with normal control group.

Effect on risk ratio: It was clear from table 3 and Figure 8 that the administration of STZ to rats elicited the highest risk value as compared to normal control group and other diabetic treated groups and the best group that succeed in reducing the risk factor is the diabetic group treated with Metformin $/ \mathrm{Cr}^{+3}$ and this group showed non-significant increase in risk ratio as compared to a normal control group. The results revealed that the diabetic group treated with Metformin $/ \mathrm{Cr}^{+3}$ showed the lowest risk ratio as compared to control group and the diabetic untreated group followed by diabetic group treated with Metformin.
The chromium salt treated group elicited slight significant increase in risk ratio as compared to normal control group but still much better than other diabetic groups.

Free fatty acids can lead to ROS release and contribute to mitochondrial DNA damage and impaired pancreatic $\beta$-cell function [47]. In patients with type $2 \mathrm{DM}$, skeletal muscle mitochondria have been described to be smaller than those in control subjects [48]. In addition, a decrease in the levels of mitochondrial proteins and mitochondrial DNA in adipocytes has been correlated with the development of type 2 DM [49]. Insulin resistance in the elderly also has been associated with elevation in fat accumulation and reduction in mitochondrial oxidative and phosphorylation activity [50]. An association also exists with insulin resistance and the impairment of intracellular fatty acid metabolism in young insulin-resistance offspring of parents with type 2 DM [51] and this greatly agreed with our results that confirming the increased level of fatty acids and increasing the level of LDL , Triglycerides and cholesterol and decreasing their levels significantly in diabetic group treated with Metformin $/ \mathrm{Cr}^{+3}$ as compared to normal control group and this is correlates to $\mathrm{Cr}^{+3}$ role in decreasing fatty acids level and thus enhancing the properties of Metformin.

Effect on insulin level: Concerning the effect of Metformin and their $\mathrm{Cr}^{+3}$ complexes on insulin level, the results revealed that administration of Metformin $/ \mathrm{Cr}^{+3}$ complexes afforded non-significant increase in insulin level as compared to normal control group while administration of STZ only to rats elicited significant decrease in insulin level when compared to normal control group. The other diabetic treated group with Metformin elicited significant decrease in insulin level by $60 \%$ as compared to normal control group as shown in table 4 . There is no significant changereported in group treated with chromium salt treated group. The $\mathrm{Cr}$ (III) interact with the insulin and its receptors on the first step in the metabolism of glucose entry into the cell, and facilitates the interaction of insulin with its receptor on the cell surface [65] and thus our results come in harmony with these findings as the combination of Metformin with $\mathrm{Cr}^{+3}$ increased the level of insulin in diabetic rats and the best results was shown in diabetic group treated with Metformin $/ \mathrm{Cr}^{+3}$ as they showed the high value of insulin level by $1.76 \%$ as compared to normal control group and by $65.11 \%$ increment as compared to diabetic untreated group and this go side by side in 


\begin{tabular}{|c|c|c|}
\hline Groups & $\begin{array}{c}\text { Insulin }(\boldsymbol{\mu U} / \mathrm{ml}) \text { in pancreatic } \\
\text { homogenates }\end{array}$ & Serum C-peptide $(\mathbf{p m o l} / \mathbf{m L})$ \\
\hline $1^{\text {st }}$ & $17.52 \pm 1.05^{\mathrm{ab}}$ & $3.87 \pm 1.01^{\mathrm{ab}}$ \\
\hline $2^{\text {nd }}$ & $6.22 \pm 0.53^{\mathrm{e}}$ & $1.12 \pm 1.03^{\mathrm{d}}$ \\
\hline $3^{\text {rd }}$ & $12.43 \pm 1.51^{\mathrm{d}}$ & $2.44 \pm 1.25^{\mathrm{c}}$ \\
\hline $4^{\text {th }}$ & $15.55 \pm 1.87^{\mathrm{c}}$ & $3.85 \pm 1.34^{\mathrm{b}}$ \\
\hline $5^{\text {th }}$ & $16.99 \pm 0.96^{\text {bc }}$ & $3.45 \pm 1.10^{\mathrm{b}}$ \\
\hline
\end{tabular}

Table 4: Effect of Metformin and Metformin $/ \mathrm{Cr}^{+3}$ complex on insulin level and serum C-peptide in normal and diabetic rat.

Data presented as mean \pm S.E. $(n=10)$.

Means within the same column in each category carrying different litters are significant at $(P \leq 0.05)$ using Duncan's multiple range tests, where the highest mean value has symbol (a) and decreasing in value were assigned alphabetically. $1^{\text {st }}$ group: control, $2^{\text {nd }}$ group: STZ, $3^{\text {rd }}$ group: STZ+Metformin, $4^{\text {th }}$ group: STZ + Metformin $/ \mathrm{Cr}+3,5^{\text {th }}$ group: $\mathrm{STZ}+\mathrm{CrCl}_{3} \cdot 6 \mathrm{H}_{2} \mathrm{O}$.

confirming our results that reported the success of $\mathrm{Cr}^{+3}$ complexes with Metformin in reducing blood glucose level and increasing insulin level and thus alleviating the side effects of diabetes mellitus and improving characterization of Metformin $/ \mathrm{Cr}^{+3}$.So we consider the first author to clarify this improving effect of Metformin $/ \mathrm{Cr}^{+3}$ on diabetes mellitus reducing complications. Chromium increases insulin binding to cells, insulin receptor number as well as activates insulin receptor kinase leading to increase sensitivity of insulin receptor [66].

Effect on serum C-peptide: It was apparent from Table 4 that administration of Metformin $/ \mathrm{Cr}^{+3}$ afforded non-significant increase in C-Peptide as compared to normal control group while the diabetic untreated group showed the less serum C-Peptide value among all the diabetic treated groups, while administration of Metformin only induced significant decrease in c-Peptide as compared to control group but showed significant increase in c-peptide as compared to normal control group. $\mathrm{CrCL}_{3} \cdot \mathrm{H}_{2} \mathrm{O}$ treated group elicited non-significant decrease in serum C-peptide level as compared to normal control group. The connecting peptide, or C-peptide, is a short 31-amino-acid protein that connects insulin's A-chain to its B-chain in the proinsulinmolecule. In the insulin synthesis pathway, first preproinsulin is translocated into the endoplasmic reticulum of beta cells of the pancreas with an A-chain, a C-peptide, a B-chain, and a signal sequence.

Measuring C-peptide can help to determine how much of natural insulin is producing as C-peptide is secreted in equimolar amounts to insulin. C-peptide levels are measured instead of insulin levels because C-peptide can assess a person's own insulin secretion even if they receive insulin injections, and because the liver metabolizes a large and variable amount of insulin secreted into the portal vein but does not metabolize C-peptide, meaning blood C-peptide may be a better measure of portal insulin secretion than insulin itself [67]. A very low C-peptide confirms Type 1 diabetes and insulin dependence and is associated with high glucose variability, hypoglycaemia and increased complications and this is an important concept that explain our findings as the more c-peptide value was found in diabetic group treated with Metformin $/ \mathrm{Cr}^{+3}$ and thus we can say the higher C-peptide, the higher insulin level and to best our knowledge, this is the first report on the effect of Metformin $/ \mathrm{Cr}^{+3}$ on ameliorating the C-peptide value and consequently increased insulin level.

\section{Ultrastructural results}

Acinar cells: Ultrastructure of control pancreas showed acinar cells with euchromatic nuclei, well-developed cisternae of rough endoplasmic reticulum, mitochondria and numerous electron dense secretory granules of variable sizes in the apical part (Figure 9a).

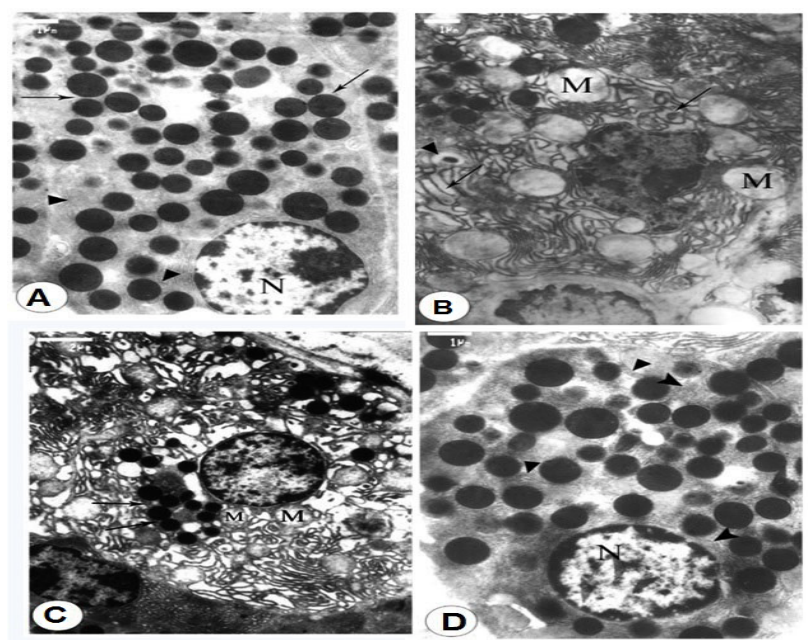

Figure 9: Exocrine part. Electron micrograph of rat pancreas showing:

(a) Control acinar cells with euchromatic nuclei $(\mathrm{N})$, well-developed cisternae of rough endoplasmic reticulum (arrow heads), mitochondria and numerous electron dense secretory granules (arrows) of variable sizes in the apical part Scale bar=1 Im. b): Electron micrograph of STZ-diabetic rat pancreas showing

(b) Damaged mitochondria (M), auotophagic vacuole (arrow head), dilated rough endoplasmic reticulum (arrows) and irregular contours of nuclei. Scale bar=1 $\mathrm{Im}$.

(c) $\mathrm{STZ}+\mathrm{Mfn}-\mathrm{HCl}$ group showing marked changes in pancreatic acini represented by damaged mitochondria $(M)$, dilated rough endoplasmic reticulum, decrease of secretory granules (arrows) and cytoplasmic vacuolation. Scale bar $=2 \mathrm{Im}$.

(d) $\mathrm{STZ}+\mathrm{Mfn}-\mathrm{HCl} / \mathrm{Cr}^{+3}$ showing marked improvement represented by increase in zymogen granules, regular contours of nuclei $(\mathrm{N})$ and flattened rough endoplasmic (arrow heads) except few vacuoles. Scale bar=1 Im.

Electron microscopic examination of the diabetic untreated group showed marked changes in pancreatic acini represented by dilated rough endoplasmic reticulum, a decrease of secretory granules, cytoplasmic vacuolation, damaged mitochondria, auotophagicvacoule and irregular contours of nuclei (Figure 9b). STZ + Metformin group showed marked changes in pancreatic acini represented by damaged mitochondria $(\mathrm{M})$, dilated rough endoplasmic reticulum, decrease of secretory granules and cytoplasmic vacuolation (Figure 9C). Pancreatic acini after supplementation with Metformin/ $/ \mathrm{Cr}^{+3}$ in diabetic rats showed marked improvement represented by increase in zymogen granules, regular contours of nuclei and flattened rough endoplasmic reticulum except few vacuoles (Figure 9d). Electron microscopic examination confirmed the presence of apoptotic changes manifested as nuclear pyknosis, indentation of nuclear membrane, chromatin release into the cytoplasm, swollen mitochondria, dilation of Golgi apparatus vesicles and disappearance of secretary granules in STZ diabetic group and the amelioration in these changes was clearly appeared in metformin $/ \mathrm{Cr}^{+3}$ diabetic treated group.

\section{Conclusion}

The chemical interaction between chromium (III) chloride hexahydrate and metformin $\mathrm{HCl}(\mathrm{Mfn} . \mathrm{HCl})$ produce diabetic mimetic model of chromium (III) metformin hydrochloride. The infrared spectroscopic results were proven that metformin hydrochloride reacted with chromium (III) ions as a bidentate ligand through its two imino groups. The chromium (III) Metformin complex has succeeded in decreasing blood glucose parametersin diabetic rats and proving its antidiabetic performance and thus proving the efficiency of metformin and Chromium (III) complex in elevating antioxidant capacities. 
Citation: El-Megharbel SM (2015) Synthesis, Characterization and Antidiabetic Activity of Chromium (III) Metformin Complex. J Microb Biochem Technol 7: 065-075. doi:10.4172/1948-5948.1000184

\section{Acknowledgment}

I introduce my deeply thankful to Dr.Reham Zakaria Hamza (Zagazig University, Faculty of Science, Zoology department) due to her role in biological part and carrying out the part of experimental animals.

\section{References}

1. WHO (2013) WHO report of world diabetes day "Eastern Mediterranean Region".

2. Bhowmik D, Chiranjib B, Yadav J, Chandira MR (2009) Formulation and InVitro Evaluation of Mouth Dissolving Tablets of Phenytoin Sodium Using Different Disintegrating Agents J Chem Pharm Res 1: 38-53.

3. Hariprasath K, Deepthi B, Sudheer Babu I, Venkatesh P, Sharfudeen S, et al (2010) Transition metal complexes and their application in drugs and cosmetics - A Review J Chem Pharm Res 2: 496-499

4. Krejpcio (2001) Spectrochemical Analysis of Soil around Leather Tanning Industry Using Laser Induced Breakdown Spectroscopy. J Environ Studies 10: 399-404.

5. Vincent JB (2007) The Nutritional Biochemistry of Chromium (III). Elsevier, 139-151.

6. Anderson RA (2000) Chromium in the prevention and control of diabetes Diabetes Metab 26: 22-27.

7. Nathan DM, Buse JB, Davidson MB, Ferrannini E, Holman RR, et al. (2009) Medical management of hyperglycemia in type 2 diabetes: a consensus algorithm for the initiation and adjustment of therapy: a consensus statement of the American Diabetes Association and the European Association for the Study of Diabetes. Diabetes Care 32: 193-203.

8. Scarpello JH, Howlett HC (2008) Metformin therapy and clinical uses. Diab Vasc Dis Res 5: 157-167.

9. Selwood PF (1956) Magnetochemistry (2nd edn), Wiley, New York.

10. Hounsom L, Horrobin DF, Tritschler H, Corder R, Tomlinson DR (1998) A lipoic acid-gamma linolenic acid conjugate is effective against multiple indices of experimental diabetic neuropathy. Diabetologia 41: 839-843.

11. Majithiya JB, Balaraman R (2006) Metformin reduces blood pressure and restores endothelial function in aorta of streptozotocin-induced diabetic rats. Life Sci 78: 2615-2624.

12. Osar Z, Samanci T, Demirel GY, Damci T, llkova H (2004) Nicotinamide effects oxidative burst activity of neutrophils in patients with poorly controlled type 2 diabetes mellitus. Exp Diabesity Res 5: 155-162.

13. Sanford HS (1954) Comparative study on the protective effect of Biphenyl Dimethyl Dicarboxylate (DDB) and Silymarin in Hepatitis induced by carbon tetrachloride $(\mathrm{CCl} 4)$ in rats. Science 119: 100.

14. Muruganandan S, Scrinivasan K, Gupta S, Gupta PK, La J (2005) Effect of mangiferin on hyperglycemia and atherogenicity in streptozotocin diabetic rats. J Ethnopharmacol 97: 497-501.

15. Prakasam A, Sethupathy S, Pugalendi KV (2003) Hypolipidaemic effect of Casearia esculenta root extracts in streptozotocin-induced diabetic rats. Pharmazie 58: 828-832.

16. Ohkawa H, Ohishi N, Yagi K (1979) Assay for lipid peroxides in animal tissues by thiobarbituric acid reaction. Anal Biochem 95: 351-358.

17. Rukmini MS, D'Souza B, D'Souza V (2004) Superoxide dismutase and catalase activities and their correlation with malondialdehyde in schizophrenic patients. Indian J Clin Biochem 19: 114-118.

18. Beutler E, Duron O, Kelly BM (1963) Improved method for the determination of blood glutathione. J Lab Clin Med 61: 882-888.

19. Sasaki T, Matsy S, Sonae A.Rinshbo Kagaku (1972) Evaluation of antihyperlipidemic activity of ethanolic extract of Cassia auriculata flowers. Asian Pac J Trop Biomed 1: 346-353.

20. Drabkin DL, Austin JM (1932) Effect of Biophytum sensitivum on streptozotocin and nicotinamide-induced diabetic rats. J Biol Chem 98: 719-733.

21. Nayak SS, Pattabiraman TN (1981) A new colorimetric method for the estimation of glycosylated hemoglobin. Clin Chim Acta 109: 267-274.

22. Bannon $\mathrm{P}$ (1982) Effect of $\mathrm{pH}$ on the elimination of the labile fraction of glycosylated hemoglobin. Clin Chem 28: 2183
23. Wu TJ, Lin CL, Taylor RL, Kao PC (1995) Proinsulin level in diabetes mellitus measured by a new immunochemiluminometric assay. Ann Clin Lab Sci 25 467-474.

24. Kumar MS, Schumacher OP, Deodhar SD (1980) Measurement of serum C-peptide immunoreactivity by radioimmunoassay in insulin-dependent diabetics. Am J Clin Pathol 74: 78-82.

25. Harris JR (1991) Electron Microscopy in Biology: A Practical Approach. (2nd edn), Oxford University Press, United Kingdom.

26. Snedecor GW (1982) Cochran WG.Statistical Methods ( $8^{\text {th }}$ edn), Ameslowa State University Press, Ames.

27. Refat MS (2007) Synthesis and characterization of norfloxacin-transition meta complexes (group 11, IB): spectroscopic, thermal, kinetic measurements and biological activity. Spectrochim Acta A Mol Biomol Spectrosc 68: 1393-1405.

28. Bellamy L J (1975) The infrared spectra of complex molecules. (3rd edn), Chapman and Hall, London.

29. Socrates G (1980) Infrared characteristic group frequencies. (1st edn), Wiley, New York.

30. Shanmugam R, Sathyanarayana DN (1984) FTIR and Raman Spectra Compared with Ab Initio Calculated Frequency Modes for 5-Aminouracil. Spectrochim Acta A 34: 549-576.

31. Sharma A, Gupta VP, Virdi A (2004) Vibrational Spectroscopy Investigation on Aspirin Using Semi-Empirical Calculations. Indian J Pure Appl Phys 42: 251.

32. Dalton F, Hill RD, Meakins GD (1960) HF, DFT Computations and Spectroscopic Study of the Vibrational and Thermodynamic Properties of Metformin. J Chem Soc 590: 2927

33. Nakamoto K (1978) Infrared and Raman spectra of inorganic and coordination compound, (2nd edn) Wiley, New York.

34. Singh HL, Varshney AK. (2006) Synthetic and Spectroscopic Characterization of Organotin(IV) Complexes of Biologically Active Schiff Bases Derived from Sulpha Drugs Bioinorg. Chem Appl 1: 309-320.

35. Chandra S, Gupta LK. (2003) Synthesis, Spectroscopic, and Antimicrobia Studies on Bivalent Nickel and Copper Complexes of Bis(thiosemicrbazone) Orient. J Chem 19: 571.

36. Olar R, Badea M, Marinescu D, Chifiriuc MC, Bleotu C, et al. (2010) N,N dimethylbiguanide complexes displaying low cytotoxicity as potential large spectrum antimicrobial agents. Eur J Med Chem 45: 3027-3034.

37. Quan CX, Bin LH, Bang GG ( 2005) Shape Controlled Synthesis of Nano-Sized Titanium(IV) Metal-Organic Frameworks Mater Chem Phys 91: 317

38. Coats W, Redfern JP (1964) Nonisothermal Kinetics Analysis of the Dehydration of Ziprasidone Hydrochloride Monohydrate by Thermogravimetry. Nature 201: 68

39. Horowitz HH, Metzger G (1963) A New Analysis of Thermogravimetric Traces. Anal Chem 35: 1464

40. Mahfouz RM, Monshi MA, Alshehri SM, El-Salam NA, Zaid AMA ( 2001) Synth React. Inorg Met -Org Chem 31: 1873.

41. Frost AA (1961) Pearson RG.Kinetics and Mechanism,Wiley, New York.

42. Hamada MM, Shallaby AHM, El-Shafai O, El-Asmy AA (2006) Trans Met Chem 31: 522 .

43. Sharma PK, Sen AK, Dubey SN (1994) Indian J Chem 6: 291

44. EL-Metwally N, El-Asmy AA (2006) Synthesis, Spectroscopic and Pharmacological Studies of Bivalent Copper, Zinc and Mercury Complexes of Thiourea. J Coord Chem 59: 1591.

45. Xinquan X, Anbang D (1988) Synthesis, spectroscopic, thermal, free radical scavenging ability, and antitumor activity studies of cobalt(II) metformin complex. Pure Appl Chem 60: 1217.

46. Sahin K, Tuzcu M, Orhan C, Agca CA, Sahin N, et al. (2011) The effects of chromium complex and level on glucose metabolism and memory acquisition in rats fed high-fat diet. Biol Trace Elem Res 143: 1018-1030

47. Rachek LI, Thornley NP, Grishko VI, LeDoux SP, Wilson GL (2006) Protection of INS-1 cells from free fatty acid-induced apoptosis by targeting hOGG1 to mitochondria. Diabetes 55: 1022-1028.

48. Kelley DE, He J, Menshikova EV, Ritov VB (2002) Dysfunction of mitochondria 
Citation: El-Megharbel SM (2015) Synthesis, Characterization and Antidiabetic Activity of Chromium (III) Metformin Complex. J Microb Biochem Technol 7: 065-075. doi:10.4172/1948-5948.1000184

in human skeletal muscle in type 2 diabetes. Diabetes 51: 2944-2950.

49. Choo HJ, Kim JH, Kwon OB, Lee CS, Mun JY, et al. (2006) Mitochondria are impaired in the adipocytes of type 2 diabetic mice. Diabetologia 49: 784-791.

50. Petersen KF, Befroy D, Dufour S, Dziura J, Ariyan C, et al. (2003) Mitochondrial dysfunction in the elderly: possible role in insulin resistance. Science 300: 1140-1142.

51. Petersen KF, Befroy D, Dufour S, Dziura J, Ariyan C, et al. (2003) Mitochondrial dysfunction in the elderly: possible role in insulin resistance. Science 300: 1140-1142.

52. Maiese K (2008) Triple play: promoting neurovascular longevity with nicotinamide, WNT, and erythropoietin in diabetes mellitus. Biomed Pharmacother 62: 218-232.

53. Chong ZZ, Li F, Maiese K (2005) Employing new cellular therapeutic targets for Alzheimer's disease: a change for the better? Curr Neurovasc Res 2: 55-72.

54. Li F, Chong ZZ, Maiese K (2006) Cell Life versus cell longevity: the mysteries surrounding the NAD+ precursor nicotinamide. Curr Med Chem 13: 883-895.

55. Li F, Chong ZZ, Maiese K (2004) Navigating novel mechanisms of cellular plasticity with the NAD+ precursor and nutrient nicotinamide. Front Biosci 9: 2500-2520.

56. Maiese K, Chong ZZ (2003) Nicotinamide: necessary nutrient emerges as a novel cytoprotectant for the brain. Trends Pharmacol Sci 24: 228-232.

57. Chong ZZ, Lin SH, Maiese K (2002) Nicotinamide modulates mitochondrial membrane potential and cysteine protease activity during cerebral vascular endothelial cell injury. J Vasc Res 39: 131-147.

58. Aoyagi S, Archer TK (2008) Nicotinamide uncouples hormone-dependent chromatin remodeling from transcription complex assembly. Mol Cell Biol 28 30-39.

59. Maiese K, Chong ZZ, Shang YC (2007) Mechanistic insights into diabetes mellitus and oxidative stress. Curr Med Chem 14: 1729-1738.

60. Krejpcio Z (2001) Spectrochemical Analysis of Soil around Leather Tanning Industry Using Laser Induced Breakdown Spectroscopy. J Pol Environ Studies 10: 399-404.

61. Chandramohan G, Ignacimuthu S, Pugalendi KV (2008) A novel compound from Casearia esculenta (Roxb.) root and its effect on carbohydrate metabolism in streptozotocin-diabetic rats. Eur J Pharmacol 590: 437-443.

62. Sahin K, Tuzcu M, Orhan C, Agca CA, Sahin N, et al. (2011) The effects of chromium complex and level on glucose metabolism and memory acquisition in rats fed high-fat diet. Biol Trace Elem Res 143: 1018-1030.

63. Ghiasi SE, Valizadeh R, Rajabian R, Jalal R, Azimian B (2010) Effects of dietary chromium-methionine supplementation on blood metabolites and insulin resistance index in fructose-fed diabetic rats. J Anim Vet Adv 9: 2284-2289.

64. Ahmed F, Urooj A (2009) Evaluation of phytochemical screening and in vitro antioxidant activity of ethanolic and hydroethanolic extracts of the fruits and twigs of ficus ovata vahl J Young pharm 1: 160-164.

65. Vincent JB (2007) The Nutritional Biochemistry of Chromium(III). Elsevier 139 151.

66. Anderson RA (2000) Chromium in the prevention and control of diabetes. Diabetes Metab 26: 22-27.

67. Clark PM (1999) Assays for insulin, proinsulin(s) and C-peptide. Ann Clin Biochem 36 : 541-564. 